\title{
PENGAMBILAN KEPUTUSAN DALAM MELAKUKAN ABORSI OLEH PEREMPUAN USIA 20-30 TAHUN
}

\author{
Edelwis Tiara Poespa Mayendri ${ }^{1 *}$, Edi Prihantoro ${ }^{1}$, \\ ${ }^{1}$ Program Studi IImu Komunikasi, Fakultas IImu Komunikasi, Universitas Gunadarma, Depok, Indonesia \\ E-mail: Edelwis.Tiara.p.m@gmail.com*,Ediprie@gmail.com
}

Received: June 19, 2020 / Revised: October 7, 2020 / Accepted: December 25, 2020

DOI: https://doi.org/10.36782/ijsr.v2i2.38

\begin{abstract}
ABSTRAK
Kebebasan dalam mengaborsi telah dikemas menutupi fakta sesungguhnya, artinya segelintir masyarakat mengetahui akan bahaya nya aborsi, namun tempat penjualan obat aborsi ilegal masih bisa mengepakkan sayap nya untuk berjualan di dunia perdagangan online. Pengabdian ini membahas Pengambilan Keputusan dalam melakukan Aborsi oleh Perempuan Usia 20-30 Tahun. Krisis pengetahuan tentang edukasi seksual membuat para pelaku aborsi kurang mengetahui mengenai bahaya Aborsi, artinya masyarakat kurang memahami betul boleh dan tidaknya jika melakukan aborsi. Aborsi dilakukan bukan hanya karena kesengajaan atau keinginan. Proses dalam mengambil keputusan pelaku aborsi pun berbeda, pengambilan keputusan yang membuat bimbang saat sudah hamil pun sulit dilakukan, minimnya pengetahuan dan terjerumus dalam pilihan yang sulit membuat masyarakat melakukan hal yang tidak seharusnya dilakukan, bagaimana proses pengambikan keputusan pada pelaku aborsi. Oleh karenanya, penelitian ini menggunakan metode pengabdian kulitatif dan menggunakan teori Pengambilan Keputusan sebagai pisau analisis pada Pengambilan Keputusan dalam melakukan Aborsi oleh Perempuan Usia 20-30 Tahun. Kasus ini diambil mengingat tingkat aborsi di Indonesia yang sangat tinggi, dan kematian ibu akibat aborsi yang sedang menjadi perhatian. Sehingga pendekatan pengabdian ini menggunakan pendekatan Fenomenologi untuk mengetahui Pengambilan Keputusan dalam melakukan Aborsi oleh Perempuan Usia 20-30 Tahun. Fenomenologi berusaha mengidentifikasi mengungkap sebuah makna dibalik cara pengambilan keputusan pada pelaku aborsi, sehingga yang ditonjolkan adalah proses pengambilan keputusan pelaku aborsi.
\end{abstract}

Kata kunci: Aborsi, Era Millennial, Pelaku Aborsi, Pengambilan Keputusan.

\section{ABSTRACT}

Freedom in abortion has been packaged to cover up the real facts, meaning that few people know about the dangers of abortion, but places selling illegal abortion drugs can still flap their wings to sell in the world of online commerce. This dedication discusses the decision making in having an abortion by women aged 20-30 years. The crisis of knowledge about sexual education makes abortion perpetrators less aware of the dangers of abortion, meaning that the community does not really understand whether or not they can have an abortion. Abortion is done not only because of intention or desire. The process of making decisions about abortion perpetrators is also different, making decisions that make doubts when pregnant are difficult, lack of knowledge and falling into difficult choices make people do things that shouldn't be done, 
how is the process of making decisions about abortion perpetrators. Therefore, this study uses a dedication method and uses the theory of decision making as a knife of analysis in decision making in performing abortion by women aged 20-30 years. This case was taken considering that the rate of abortion in Indonesia is very high, and maternal mortality due to abortion is a concern. So that this service approach uses a phenomenological approach to determine the decision making in carrying out abortion by women aged 20-30 years. Phenomenology tries to identify a meaning behind the way the abortion perpetrator takes decisions, so that what is highlighted is the abortion perpetrator's decision-making process.

Keywords: Abortion, Abortion Actors, Decision Making, Millennial Era.

\section{PENDAHULUAN}

Kamus Hukum "Aborsi" adalah penghentian atau penggagalan kehamilan atau pengguguran anak dalam kandungan dengan menggunakan cara yang melawan hukum, sedangkan "Abortus" adalah gugurnya anak yang ada di dalam kandungan karena kelahiran sebelum waktunya tanpaadanya unsur kesengajaan di dalam prosesnya (Utami, 2015).

Aborsi merupakan keputusan bagi sebagian perempuan yang telah hamil di luar nikah untuk menghindari hal-hal yang tidak mereka inginkan ke depannya. Dalam melakukan aborsi pun tidak lah sulit, banyak link atau web yang bisa di akses dengan mudah untuk melancarkan aksinya.

Media online tak henti-hentinya menjadi wadah dalam pencarian obat penggugur kandungan. Maraknya peminat membuat penjual memberikan tanggapan terhadap perkembangan sosial sebagai tempat transaksi penjualan.

Kasus baru-baru ini membuat getir masyarakat, pasalnya terdapat klinik aborsi di Jalan Paseban yang menggugurkan 903 Janin (dikutip dari berita CNN Nasional). Praktik aborsi ini dijalankan oleh Dokter dan Bidan yang merupakan residivis dan sudah menggugurkan 903 janin. Pengungkapan tersebut bermula dari informasi masyarakat tentang aborsi ilegal di klinik tanpa nama, dan praktik ini pun dikonfirmasikan secara online. Klinik tersebut telah beroperasi 21 bulan. Tercatat ada 1.632 pasien yang mendatangi klinik dan 903 diantaranya sudah menggugurkan kandungannya.

Kasus aborsi yang terjadi di Indonesia sangat menarik untuk diteliti karna berbagai motif yang menjadi alasan utama untuk sadar melakukan perbuatan tercela dan diakhiri dengan menggugurkan kandungan membuat penulis bertanya-tanya bagaimana proses pengambilan keputusan seorang pelaku aborsi, apakah pelaku aborsi melakukannya dalam keadaan sadar atau adakah faktor lainnya. Menurut KBBI (Kamus Besar Bahasa Indonesia) aborsi adalah pengguguran kandungan, kriminalis aborsi yang dilakukan dengan sengaja karena suatu alasan dan bertentangan dengan undang-undang yang berlaku, legal aborsi yang dilaksanakan dengan sepengetahuan pihak yang berwenang.

Suryo Darmono dari Rumah Sakit Carolus mengatakan tindakan aborsi banyak yang dilakukan secara mendadak serta tanpa sepengetahuan orangtua pelaku aborsi bersangkutan. Hasilnya, 
pelaku aborsi perempuan menjadi traumatik dengan tindakan aborsi tersebut (Abrori, 2014).

Tindakan aborsi menurut kitab Undang-Undang dikategorikan tindakan kriminal atau dikategorikan sebagai kejahatan terhadap nyawa. Pasal-pasal KUHP yang mengatur hal ini adalah Pasal 229, 346349, dan 535. Melakukan aborsi baik secara legal maupun illegal kepada janin yang tidak berdosa baik orang yang mengandungnya maupun orang lain yang membantu untuk melakukan perbuatan tersebut sama-sama dijerat dengan pasal ini (Ranoemiharja, 1991).

Menurut KUHP, aborsi adalah pengeluaran hasil konsepsi pada setiap stadium perkembangannya sebelum masa kehamilan yang lengkap tercapai (38 - 40 minggu). Pengeluaran hasil konsepsi sebelum janin dapat hidup di luar kandungan (berat kurang dari 500 gram atau kurang dari 20 minggu). Dari segi medikolegal maka istilah abortus, keguguran, dan kelahiran prematur mempunyai arti yang sama dan menunjukan pengeluaran janin sebelum usia kehamilan yang cukup.

Aborsi hanya boleh dilakukan hanya untuk dua kondisi kemungkinan kehamilan saja, yaitu kehamilan karena perkosaan dan aborsi karena darurat medis. Aborsi yang dilakukan dalam kasus kehamilan hasil perzinaan dan gagal KB termasuk aborsi ilegal. Salah satu pasal yang mengatur tentang aborsi yaitu Pasal 348 Ayat 1 menyebutkan Siapa yang dengan sengaja menggugurkan atau menghabisi nyawa kandungan seorang wanita dengan persetujuannya, diancam dengan pidana penjara paling lama lima tahun enam bulan. Dan jika perbuatan tersebut mengakibatkan matinya wanita tersebut, dikenakan pidana penjara paling lama tujuh tahun.

Pelaku aborsi juga merasa tidak percaya diri akan penampilannya yang terlalu diperhatikan oleh orang lain, jika seseorang berdiri terlalu dekat atau terlalu jauh dan jika kontak mata seseorang terlihat aneh atau jika seseorang menyimpangkan beberapa dugaan, maka akan menimbulkan rasa tidak nyaman, dan menimbulkan fikiran negatif (Littlejhon, 2011).

Di samping itu, banyak perempuan merasa mempunyai hak atas mengontrol tubuhnya sendiri, sehingga merasa bebas melakukan apa saja terhadap tubuhnya. Di sisi lain, dari segi ajaran agama manapun tidak akan memperbolehkan manusia melakukan tindakan penghentian kehamilan dengan alasan apapun. Sedangkan dari segi hukum, masih adanya perdebatan dan pertentangan dari yang pro dan yang kontra soal persepsi atau pemahaman mengenai undangundang yang ada sampai saat ini. Baik dari UU kesehatan, UU praktik kedokteran, kitab undangundang hukum pidana (KUHP), UU penghapusan kekerasan dalam rumah tangga (KDRT), dan UU hak azasi manusia (HAM). Keadaan seperti di atas inilah dengan begitu banyak permasalahan yang kompleks yang membuat banyak timbul praktik aborsi gelap, 
yang dilakukan baik oleh tenaga medis formal maupun tenaga medis informal. Baik yang sesuai dengan standar operasional medis maupun yang tidak, yang kemudian menimbulkan komplikasi mulai dari komplikasi ringan sampai yang menimbulkan kematian. Pasien berkata dalam hatinya "aku harus kuat menjalani perawatan dan terapi ini agar aku bisa sembuh" itu merupakan salah satu contoh dalam komunikasi intrapersonal dalam memotivasi diri (Harahap, 2019).

Dalam pengabdian ini penulis sangat tertarik untuk mengungkap sebuah makna bagaimana proses pengambilan keputusan pelaku aborsi, dengan fokus pada bidang komunikasi yang mengkonstruk pelaku aborsi untuk melihat bagaimana proses komunikasi pada dirinya sendiri dalam proses pengambilan keputusan sehingga mendapatkan sebuah penemuan bagaimana caranya untuk mencegah perbuatan ini agar tidak terulang kembali dan mampu menurunkan tingkat kematian anak di Indonesia. Berdasarkan latar belakang diatas maka peneliti tertarik untuk meneliti tentang Pengambilan Keputusan dalam melakukan Aborsi oleh Perempuan Usia 20-30 Tahun. Melalui kajian dengan menggunakan teori pengambilan keputusan yang dikemukakan oleh Russel-Jones (2000), dalam tahapan pengambilan keputusan, sebagai pisau analisis dan pendekatan fenomenologi mengingat banyaknya pelaku aborsi di Indonesia saat ini.

\section{METODOLOGI}

\section{A. Subjek Pengabdian}

Kriteria subjek pengabdian ini adalah pelaku aborsi AP (22 Tahun), NF (22 Tahun) dan OS (22 Tahun) yang telah melakukan aborsi yang menjadi faktor utama penyebab tingkat aborsi di Indonesia membuat perihatin lebih baru-baru ini. Pelaku aborsi tersebut peneliti melakukan wawancara kepada informan melalui chatting dan via pesawat telepon terkait dengan Fenomena melakukan aborsi di Era Millennial.

\section{B. Objek Penelitian}

Supranto (2000) bahwa objek penelitian adalah himpunan elemen yang dapat berupa orang, organisasi atau barang yang diteliti (Fitrah, 2017:160).

Obyek pengabdian adalah pokok persoalan yang hendak diteliti untuk mendapatkan data secara lebih terarah. Adapun Objek pengabdian dalam pengabdian ini adalah predisposisi pelaku aborsi dilihat dari proses pengambilan keputusan dan bagaimana keterbukaan pelaku aborsi, mengingat bagaimana praktik aborsi di Era Millennial (Predisposisi personal pelaku aborsi).

Janis \& Mann (1977), menyebutkan bahwa pengambilan keputusan merupakan pemecahan masalah dan terhindar dari faktor situasional. Dalam pengabdian ini menempatkan Pengambilan Keputusan berada dalam Paradigma Konstruktivis 
dimana pengabdian berusaha untuk mengungkap sebuah makna dibalik motif dan faktor pelaku aborsi melakukan aborsi yang mengindikasikan pada bidang komunikasi untuk melihat bagaimana pelaku aborsi mengambil keputusan sehingga melakukan aborsi, bisa dilakukan dengan menggunakan pendekatan fenomenologi karna melihat fenomena aborsi yang menjadi perhatian lebih untuk Indonesia, di mana data dikumpulkan melalui pengabdian lapangan secara online (online field research) yaitu via chatting dan telepon.

Pengabdian ini menggunakan metode pengabdian kualitatif. Tujuan penggunaan metode kualitatif ini adalah untuk mengenal objek yang di teliti (Ikbar, 2012). Pengabdian kualitatif berusaha menjelaskan makna tentang suatu fenomena berdasarkan pandangan-pandangan partisipan. Pengabdian yang dilakukan pada kondisi objek yang alami, peneliti sebagai instrumen kunci, teknik pengumpulan data dilakukan secara gabungan, data yang dihasilkan bersifat deskriptif, dan pengabdian ini lebih menekankan makna dari pada generalisasi. Pengabdian ini dimulai pada bulan Februari.

Teori Pengambilan Keputusan dengan Paradigma Konstruktivis akan mengajukan pertayaan tentang bagaimana proses pengambilan keputusan dari pelaku aborsi. Teori ini sangat cocok untuk dipadupadankan dalam memaknai dan menemukan bagaimana proses pengambilan keputusan dari pelaku aborsi dengan pendekatan fenomenologi dengan tujuan mengurangi angka aborsi atau kematian bayi di Indonesia.

\section{Jenis dan Sumber Data}

\section{Jenis data}

Dalam pengabdian ini digunakan dua macam data yaitu data pimer dan sekunder. Di bawah ini akan di jelaskan kedua macam data tersebut.

a. Data primer yaitu data yang langsung dikumpulkan oleh penulis (atau petugasnya) dari sumber pertamanya. Adapun yang menjadi sumber data primer dalam pengabdian ini adalah pelaku aborsi yang melakukan aborsi.

b. Data sekunder, yaitu data yang langsung dikumpulkan oleh penulis sebagai penunjang dari sumber pertama. Dapat juga dikatakan data yang tersusun dalam bentuk dokumendokumen. Dalam pengabdian ini, berita, dan jurnal merupakan sumber data sekunder.

\section{Sumber data}

a. Place atau tempat adalah sumber data yang menyajikan tampilan berupa keadaan diam dan bergerak dan keadaan keduanya sebagai obyek untuk penggunaan metode observasi terhadap pelaku aborsi.

b. Data tertulis adalah sumber data yang menyajikan tanda-tanda berupa huruf, angka, gambar, simbol-simbol dan lain-lain. Ini digunakan pada metode dokumentasi berita- 
berita yang menunjang dan data dari ahli psikolog.

\section{HASIL DAN PEMBAHASAN}

\section{Pendapat Pelaku Aborsi}

Dalam pengertian medis, aborsi adalah terhentinya kehamilan dengan kematian dan pengeluaran janin pada usia kurang dari 20 minggu dengan berat janin kurang dari 500 gram, yaitu sebelum janin dapat hidup di luar kandungan secara mandiri (Susanti, 2012).

Aborsi dapat didefinisikan pengguguran kandungan, kriminalis aborsi yang dilakukan dengan sengaja karena suatu alasan dan bertentangan dengan undang-undang yang berlaku, legal aborsi yang dilaksanakan dengan sepengetahuan pihak yang berwenang. Atau dapat dikatakan bahwa aborsi sama dengan pembunuhan berencana. Tepatnya pada aborsi ilegal yang dilakukan dengan sengaja oleh pelaku aborsi. Kasus aborsi di Indonesia menjadi perbincangan, sudah terpapar di sejumlah wilayah obat-obatan yang dapat menggugurkan kandungan untuk harga obatnya pun beragam. Penyedia layanan praktik aborsi pun bisa dicari melalui situs online, kasus aborsi di Jalan Paseban pun mengatakan bahwa jasanya bisa dikonfirmasikan melalui situs online, tidak sedikit yang mendaftarkan diri dan menjadi pasien. Insan masyarakat sekitar pun menginginkan klinik tersebut ditutup dan tidak beroperasi kembali.

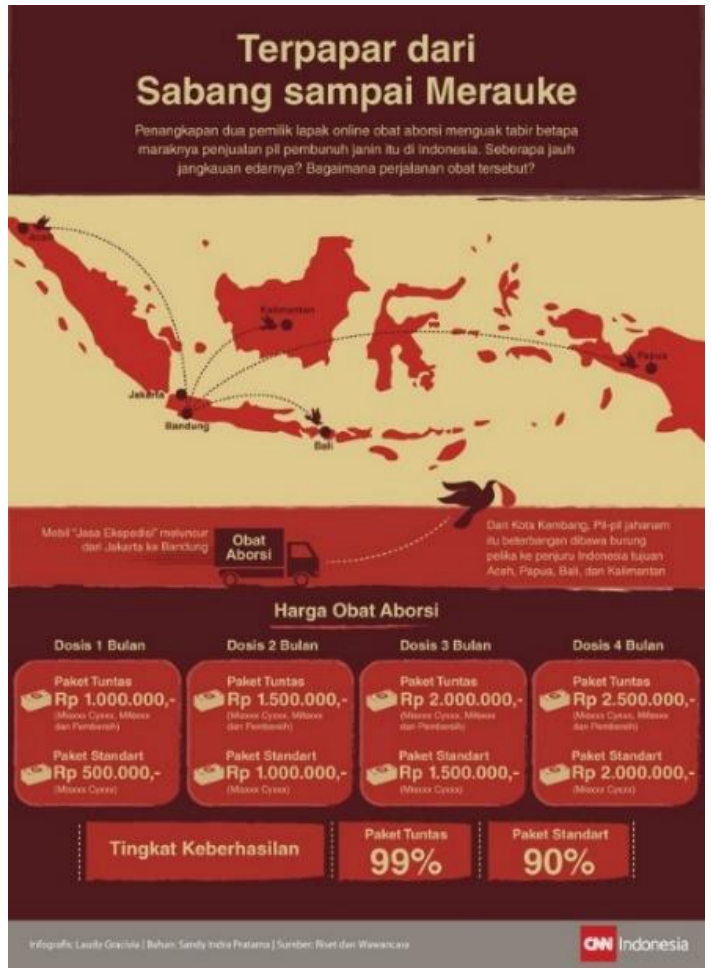

Gambar 1. Perjalan Obat Aborsi di edarkan (Sumber: CNN Indonesia, 2020)

Pada gambar terlihat dengan jelas bagaimana proses penyaluran obat aborsi yang menjadi perantara berhasilnya aborsi dilakukan oleh pelaku aborsi. Tidak hanya itu pada gambar mendeskripsikan perihal harga obat dengan kriteria janin yang ingin di aborsi, dan tingkat keberhasilannya. Gambar ini menjadi perwakilan dari sebuah iklan yang juga menjadi faktor percaya nya konsumen dengan obat aborsi yang mampu mampu melancarkan niatnya untuk melakukan aborsi.

Oleh sebab itu, siapa pun yang ingin mengaborsi kandungannya, sudah dapat mencari aksesnya dengan mudah melalui situs online sesuai dengan umur dari kandungan pelaku aborsi. Hal yang 
dikhawatirkan dalam mudahnya akses untuk mendapatkan obat untuk menggugurkan atau penyedia layanan untuk menggugurkan adalah bayi yang tak berdosa dibunuh dan semakin maraknya perilaku menyimpang yang dilakukan anak dibawah umur dengan melakukan seks bebas, bukan hanya itu, tapi kesehatan tubuhnya juga terancam.

Peneliti memutuskan untuk memilih AP (22 tahun), IF (22 tahun), dan OS (22 tahun) sebagai informan kunci. Berdasarkan observasi peneliti akan melihat proses pengambilan keputusan pada pelaku aborsi dengan mendeskripsikan jawaban dari narasumber.

\section{Tahapan Pengambilan Keputusan}

Menurut Russel-Jones (2000), ada tujuh (7) tahapan dalam suatu pengambilan keputusan, sebelum akhirnya individu melakukan tindakan. Tahapan-tahapan tersebut adalah sebagai berikut.

\section{Membuat batasan tentang keputusan apa yang harus diambil}

Individu cenderung membuat keputusan yang salah karena sebelumnya tidak menganalisa penyebab diambilnya keputusan tersebut. Pertanyaan yang sering muncul adalah "mengapa aku perlu mengambil keputusan ini?", "apa tujuannya aku mengambil keputusan ini?".

Hasil analisis menyatakan bahwa narasumber mengatakan aborsi ini dimulai dari adanya nafsu dan mempercayai pasangan, sehingga tidak ada jalan lain, dorongan yang memperlihatkan dirinya pada masa depan yang masih panjang membuat pelaku aborsi meyakini bahwa melanjutkan kehamilan bukanlah pilihan yang tepat untuk mahasiswa yang masih menjadi tanggungan kedua orangtua, faktor inilah yang menjadikan pelaku aborsi menjalankan niatnya untuk melakukan aborsi.

\section{Memahami konteks situasi dimana keputusan akan dibuat}

Konteks situasi dari keputusan yang akan diambil akan sangat mempengaruhi proses pengambilan keputusan. Pertanyaan yang mungkin akan muncul adalah "siapa-siapa saja yang berperan dalam proses pengambilan keputusan ini?", "Kepada siapa saja dampak keputusan ini akan berpengaruh?".

Hasil analisis menyatakan bahwa terdapat beberapa orang terdekat yang menjadi tempat pelaku aborsi mencurahkan permasalahan yang dihadapi sehingga menjadi alasan pelaku aborsi mampu menggugurkan kandungannya, hal ini juga yang menjawab siapa saja orang-orang yang terlibat untuk melakukan niat pelaku aborsi, antara lain teman dekatnya yang membantu menyarankan, teman pasangannya yang menyalurkan obat aborsi dan juga dorongan dari dirinya untuk tidak mempermalukan kedua orangtuanya. 


\section{Mengidentifikasi setiap pilihan yang ada}

Kesulitan yang umum terjadi dalam suatu proses pengambilan keputusan adalah kurangnya pilihan yang memungkinkan untuk diambil, khususnya ketika tidak satupun diantara pilihan tersebut yang kelihatannya sesuai dengan tujuan pengambilan keputusan. Pertanyaan yang sering muncul adalah "Pilihan-pilihan apa saja yang kumiliki", "Apakah langkah ini merupakan jalan keluar bagiku?"

Hasil analisis menyatakan bahwa 2 pelaku aborsi mengaku tidak memiliki pilihan lain selain melakukan aborsi karena sudah panik dan tidak dapat mengontrol diri serta rasa takut yang ada pada dirinya dan pada akhirnya hanya aborsi yang menjadi pilihan, namun ada 1 orang pelaku aborsi yang merasa harus mempertahankan kandungannya, namun niat baik tersebut tidak dapat dilanjutkan karena rasa kasihan pada pasangan yang belum siap menikahinya, dan kedua orangtua yang tidak merestui, nilai moral pada kesadaran kepentingan nyawa mahkluk hidup pun kalah dengan rasa sayang pada pasangannya.

\section{Mengevaluasi konskuensi dari masing-masing pilihan}

Setiap keputusan yang diambil akan menghasilkan suatu konskuensi, dan tidak akan ada artinya keputusan tersebut diambil jika individu tidak berkomitmen terhadap konskuensinya. Sejauh mana konskuensinya paling masuk akal dan sesuai dengan kebutuhanku? Sejauh mana penyesalan yang akan teradi jika aku mengambil tindakan dan tidak mengambil tindakan?

Hasil analisis menyatakan bahwa ketiga narasumber memiliki jawaban yang cenderung sama yaitu jika tidak mengambil tindakan dalam artian aborsi, maka nama kedua orangtuanya akan tercoreng, masa depan yang di susun dengan rapih hanya akan menjadi history, teman-teman yang menjadi tempat tertawa hanya akan menjadi sumber kesengsaraan karena ocehan tak berujung, untuk menghindari itu semua, pelaku aborsi menetapkan keputusannya untuk melakukan aborsi

\section{Menentukan prioritas dan memiliki satu diantaranya}

Setelah setiap konskuensi pilihan selesai dianalisa, kita harus memilih salah satu diantara serangkaian pilihan tersebut. Pada dasarnya tidak melakukan apapun tetaplah sebuah keputusan. Dari hasil wawancara ketiga narsumber memiliki prioritas yang sama yaitu kedua orang tua, keluarga dan masa depan yang cerah, sehingga harus melakukan aborsi, narasumber merasa apa yang dilakukan adalah benar demi tujuan yang matang dan panjang.

\section{Menelaah ulang keputusan yang dipilih}

Pada satu titik setelah keputusan diambil, individu tetap harus menelaah ulang keputusan yang telah diambilnya. Frekuensi dan kedalamannya 
tergantung dari seberapa besar keputusan tersebut mempengaruhi kebutuhannya.

Ketiga narasumber sudah menelaah kembali keputusan yang diambil dengan mempertimbangkan apa yang akan terjadi dan didapatkan apabila tidak melakukan aborsi.

\section{Mengambil tindakan terhadap keputusan yang dipilih}

Setelah keputusan diambil, sebuah tindakan harus dilakukan sebagai bentuk impelementasinya. Tidak akan ada artinya proses pengambilan keputusan yang sudah dilalui apabila individu tidak membuat suatu tindakan apapun. Ketiga narasumber sudah melakukan aborsi dan memilih untuk melakukan aborsi, tindakan yang dipilih adalah dengan melakukan aborsi, narasumber sudah melakukan implementasinya dengan melakukan aborsi dengan cara nya masing-masing mulai dari meminum obat hingga operasi.

Berdasarkan hasil analisis yang telah diuraikan, diketahui bahwa terdapat beberapa dimensi penting dalam membentuk pengambilan keputusan pelaku aborsi yaitu menentukan prioritas dan memiliki satu diantaranya, juga adanya dukungan dari dalam dan dari luar yang membuat ketiga narasumber mengambil keputusan untuk melakukan aborsi, menentukan prioritas untuk tetap menjalani hidup tanpa adanya merusak nama baik, dan masa depan yang terancam membuatnya tergerak untuk melancarkan niatnya dan juga keintensifan, dimana pelaku aborsi lebih sering bercerita dengan sahabat atau teman dekatnya yang akhirnya menjadikan faktor kepercayaan yang dapat mempengaruhi pengambilan keputusan pelaku aborsi, unsur kepercayaan kepada teman dan sahabat yang membuat pelaku aborsi merasa nyaman untuk bercerita dan berani mengambil keputusan untuk melakukan aborsi.

\section{KESIMPULAN}

Dari hasil pengabdian yang dilakukan tentang Praktik Aborsi di Era Millennial (Predisposisi Personal Pelaku Aborsi), maka penulis dapat menarik beberapa kesimpulan.

Aborsi di era millennial ini menyatakan tingginya tingkat kepercayaan pada pasangan namun tidak berpikir panjang efek apa saja yang akan didapatkan. Tingginya tingkat kepercayaan pada pasangan juga menjadi faktor utama semua ini dimulai, sehingga terdapatnya keterbatasan cara untuk menghentikan alur aborsi ini, selain adanya penyadaran diri sendiri dengan dibantu dorongan dari dalam dan dari luar untuk tidak melakukan aborsi.

Fenomena adanya aborsi di era millennial membuat segelintir masyarakat khususnya perempuan yang kritis masalah moral, kenapa? Karena pelaku aborsi dengan tega mengaborsi atau membunuh janin nya sendiri, tanpa berpikir bahwa 
sebuah nyawa itu berhak untuk hidup dan bernafas. Faktor dalam menentukan prioritas untuk tetap menjalani hidup tanpa adanya merusak nama baik, dan masa depan yang terancam membuatnya tergerak untuk melancarkan niatnya

Proses pengambilan keputusan pelaku aborsi sudah melalui beberapa tahap, mulai dari dalam keadaan sadar dihadapi permasalahan besar sampai dengan melakukan hubungan seksual di luar nikah, memahami keadaan fisik yang sedang hamil, berada dalam posisi kebingungan, hancur dan tidak ada arah, proses memahami masalah dan resiko yang dihadapi, sampai dengan memutuskan untuk melakukan aborsi. Terjadinya perang dalam diri pelaku aborsi hingga pendapat dari orangtua yang memberinya makan dan ketakutan akan omongan teman-teman serta pasangan yang tidak bertanggung jawab membuatnya mengambil jalan yang menurutnya benar.

Hasil pengabdian ini diharapkan dapat diterima dengan baik oleh pembaca dan dapat dimanfaatkan sesuai dengan tujuannya.

\section{SARAN}

Dari hasil pengabdian yang dilakukan mengenai Decision Making: Praktik Aborsi di Era Millennial, maka peneliti dapat menarik beberapa saran.

Bagi pemerintah diharapkan dapat lebih memperhatikan kondisi saat ini, tingkat kematian bayi atau janin yang belum lahir di Indonesia sangatlah tinggi, hal ini juga harus menjadi topik yang perlu di tindak lanjuti serta adanya pencegahan, dengan pengabdian ini, diharapkan mendapatkan perhatian penuh oleh pemerintah dan pihak berwajib untuk lebih diperhatikan dan diperkuat aturan yang membuat pelaku aborsi maupun penyedia layanan aborsi jera dan berhenti. Serta peneliti berharap pengabdian ini dapat segera membangun semangat pemerintah untuk dapat tergerak hatinya dan niatnya agar pembunuhan berencana ini dapat segera berakhir dengan aturan dan ketentuan yang jelas.

Bagi masyarakat bahwa dapat disadari makna dari adanya fenomena ini adalah keharusan adanya kepekaan orang sekitar yaitu masyarakat sendiri yang harusnya mampu untuk menegur dan mengingatkan pada pelayanan yang menyediakan layanan aborsi untuk menghentikan niatnya dan untuk orang tua yang lebih mengawas diri kepada anak-anaknya agar tidak terjerumus dalam pergaulan bebas, dan lebih diperhatikan lagi temanteman yang ada disekitar anaknya.

Bagi pengabdi selanjutnya diharapkan pengabdian ini dapat menjadi tolak ukur dan refrensi bagaimana fenomena aborsi di era millennial yang krisis kesadaran kepentingan individu dan dengan teori pengambilan keputusan pengabdian ini diharapkan dapat menjadi acuan yang menjadikan pengabdian selanjutnya mendapatkan perkembangan yang valid dan relevan sehingga 
adanya ketegasan dari pemerintah untuk dapat bertindak tegas.

\section{UCAPAN TERIMA KASIH}

Terimakasih kepada Allah swt yang telah memberikan saya jalan untuk dapat menemukan tempat untuk mempublikasi penulisan saya, dan juga terimakasih banyak kepada Bapak/lbu yang telah memberikan kesempatan kepada saya untuk menyediakan tempat agar pengabdian saya diterima dan di-publish, saya sangat beruntung karena telah mendapatkan kesempatan ini. Semoga Bapak/lbu yang menerima tulisan saya sehat selalu dan dilancarkan rezekinya, aamiin.

\section{DAFTAR PUSTAKA}

Abrori. (2014). Di Simpang Jalan Aborsi. Semarang: Gigih Pustaka Mandiri.

CNN Indonesia. (2020, Agustus 19). Polisi Ungkap Dua Metode Klinik Aborsi Hilangkan Bukti Janin. CNN Indonesia. Diakses dari https://www.cnnin donesia.com/nasional/20200819194610-12-53 7504/polisi-ungkap-dua-metode-klinik-aborsi-h ilangkan-bukti-janin

Harahap, R. A. (2019). Buku Ajar Komunikasi Kesehatan. Jakarta Timur: Prenademedia Group.
Ikbar, Yanuar. (2012). Metode Penelitian Sosial, Cet. II. Bandung: PT. Refika Aditama.

In L. Muh Fitrah, (2017). Metodologi Penelitian: Pengabdian Kualitatif. Bojong Genteng: CV Jejak.

Janis, I L., Mann, L. (1977). Decision Making A Psychological Analysis of Conflict, Choice, and Commitment. New York: The Free Press.

Littlejohn, Stephen W. Karen A. (2011). Theories of Human Communication. In M. Y. Hamdan, Teori Komunikasi (p. 433). Jakarta: Salemba Humanika.

Ranoemiharja, Atang. (1991). IImu Kedokteran Kehakiman. Bandung: Penerbit Tarsito.

Russell-Jones, N. (2000). The Decision Making Pocketbook. Alresford: Management Pocketbooks Ltd.

Susanti, Y. (2012). Perlindungan Hukum Bagi Pelaku $\begin{array}{lll}\text { Tindak } & \text { Pidana }\end{array}$ (Abortus Provocatus) Korban Perkosaan. Syiar Hukum: Jurnal Ilmu Hukum, 14(2), 290311.

Utami, T. K. (2015). Tanggung Jawab Dokter Dalam Melakukan Aborsi. Jurnal Hukum Mimbar Justita, 1(2), 499-517. 
Indonesian Journal for Social Responsibility (IJSR) Vol. 2, No. 02, (2020), hal. 69-79 